\title{
ANATOMY AND MORPHOMETRY OF THE SKULL OF Amazona aestiva (LINNAEUS, 1758; PSITTACIFORMES, AVES)
}

\section{ANATOMIA E MORFOMETRIA DO CRÂNIO DE Amazona aestiva (LINNAEUS, 1758; PSITTACIFORMES, AVES)}

\section{Joyce Galvão de SOUZA ${ }^{1}$; Artur da Nóbrega CARREIRO ${ }^{1}$; Brunna Muniz Rodrigues FALCÃO ${ }^{1}$; Débora Vitória Fernandes de ARAÚJO' ${ }^{2}$; Michel Gonçalves de OLIVEIRA ${ }^{2}$; Gildenor Xavier MEDEIROS ${ }^{3}$; José Rômulo Soares dos SANTOS ${ }^{4}$; Danilo José Ayres de MENEZES ${ }^{5}$}

1. Universidade Federal de Campina Grande, Programa de Pós Graduação em Ciência e Saúde Animal, Patos, PB, Brasil; 2. Universidade Federal de Campina Grande, Patos, PB, Brasil; 3. Universidade Federal de Campina Grande, Medicina Veterinária, Patos, PB, Brasil; 4. Universidade Federal de Campina Grande, Patos, PB, Brasil; 5. Universidade Federal do Rio Grande do Norte, Departamento de Morfologia, Natal, RN, Brasil.

\begin{abstract}
Obtaining craniometric data is key to establishing parameters that can help in the anatomic identification and understanding of species. The aim of the present study was to establish the craniometric data and describe the main skull bones and structures of Amazona aestiva, which has become common in veterinary clinics, originated from the legalized purchase or trafficking of animals. A total of 20 adult specimens were used, donated for studies by the Paraíba Wild Animal Screening Center (Centro de Triagem de Animais Silvestres da Paraíba (CETAS-PB)/IBAMA-PB, Brazil. The skulls were dissected and macerated with water. First were identified the frontal, maxilla, mandible, nasal, jugal and quadrate bones that served as a base to identify other bone structures that were then compared with the skull of other bird species already described in the literature, especially psitacids. Values were obtained by measuring with a digital pachymeter, and the maximum skull length was $63.0 \mathrm{~mm}$, the maximum width $33.0 \mathrm{~mm}$ and the rhamphotheca was $33.8 \mathrm{~mm}$ long. No significant differences were observed between males and females and well developed cranial kinesis was a remarkable characteristic of the species. The data obtained serve as a base to identify and characterize the species. These data can also aid in the clinic, imaging and veterinary surgery.
\end{abstract}

KEYWORDS: Morphology. Morphometry. Psittacidae.

\section{INTRODUCTION}

The family Psittacidae is part of the order Psittaciformes, and are found mainly in neotropical regions. They have a generalist diet, feeding on seeds, shoots, nuts, coconuts, fruit, flowers and other plants and insects. They are recognised atomically by the peculiar shape of the beak (short and curved, with a wide base) their zigadactyl feet (toes II and III forward-oriented and toes I and IV backward-oriented) and their colourful plumage (GRESPAN; RASO, 2014). They are among the most trafficked birds and raised as a "pet" that consequently means that they frequently need veterinary medical assistance and for this reason the study of the anatomy of this species has become essential.

The main peculiarities shown by bird skeletons are lightness and resistance. Resistance comes from the fusion of the bones, while lightness is the product of the extensions of a wide system of airbags inside many bones (FEDDUCIA, 1986). Since the nineteenth century, information obtained from the study of bird skeletons have been useful to identify similarities and differences betwen the representatives of different taxons (PASCOTTO; HÖFLING; DONATELLI, 2006). In birds, the skull is divided into the neurocranium and the splanchnocranium, separated by a large orbital cavity. In bigger birds, the neurocranium is smaller, while in small birds it is shown to be relatively large, and the splanchnocranium can be big, depending on the development of the mandible apparatus, and is related to the diet and food habits of the bird (NICKEL; SCHUMMER; SEIFERLE, 1977). A striking characteristic of bird skulls is the large orbits that house the big eyes, that are separated by a thin bone membrane, the septum interorbitale bone (FEDDUCIA, 1986).

The study of the skull is difficult because the bones under go extensive fusion during the life of the animal (SILVEIRA; HÖFLING, 2007), but descriptive studies of the peculiarities of the skull of each species can be used in a practical way for better classification, as a guide in surgical procedures and for anaesthetic access. Thus the aim of the present study was to describe the skull 
characteristics of the Amazona aestiva, and obtain data that could serve as reference for the species.

\section{MATERIAL AND METHODS}

A total of 20 adult skulls of Amazona aestiva specimens were used, 10 males and 10 females corpses donated for study by the Paraíba Wild Animal Screening Center (Centro de Triagem de Animais Silvestres da Paraíba, CETAS-PB), Brazil. All animals were identified as adults but the exact age could not be identified due to being animals from free living or trafficking. The study was carried out in the Morphological Research Laboratory of the Academic Unit of Veterinary Medicine (UAMV), Health and Rural Technology Center (CSTR), of the Federal University of Campina Grande (UFCG), Patos/PB, Brazil. Controlled maceration was carried out on the skulls during 5 days, starting by removing the skin, facias and muscles using dissection instruments. The bones were bleached with hydrogen peroxide at 5\% (LADEIRA; HÖFLING, 2007) for five minutes and the tissues cleaned again to finalize the skull preparation.

The descriptions of the bones and the craniometric data were obtained with the help of a circular cold light magnifying glass and a digital pachymeter 0-150 MM LCD Vernier Calibre Micrometer Caliper Ruler. The points measured were adapted from studies on bird skulls (SOUZA et al., 2017a; SOUZA et al., 2017b). The following measures were taken: the maximum skull length (Figure 1B) (measured from the most caudal point of the skull, immediately above the cerebellum prominence to the rostral surface of ther rhamphotheca, following a horizontal line), the maximum skull width (Figure 1B) (obtained from the distance between postorbital processes), maximum skull height without the mandible (Figure 1F) (from the condylus occipitalis to the most dorsal point of the skull roof), the maximum caudal skull width (Figure 1B) (obtained from the distance between external ear canals), the distance between paraoccipital processes (Figure 1F) (obtained between their most medial points), foramen magnum length and width (Figure $1 \mathrm{~F}$ ), jugal bone length and thickness (Figure 1A), maximum rhamphotheca width (Figure 1B), rhamphotheca length (Figure 1A) (from the tip of the rhamphotheca to zona flexoria craniofacialis), maximum gnathotheca width (Figure 1I), nares cranio-caudal length (Figure 1B), zona flexoria craniofacialis (Figure 1B), distance between the free ends of lacrimal processes (Figure 1B), condylus occipitalis (Figure 1F), orbits diameter (Figure 1A), distance between the orbits (between the most cranial points, followed by the frontal bones) (Figure 1B) and pterygoides bone length (Figure 1E).

The abbreviations used in the images and tables are adapted from previous studies on bird skulls (LADEIRA; HÖFLING, 2007; MARCELIANO; DONATELLI; POSSO, 2007; CALONGE-MÉNDEZ; HÖFLING, 2007; GUZZI et al., 2015A).

The research was submitted and approved by the Committee of Ethics in Research /CSTR/UFCG under protocol CEP 090.2017 and in the SISBIO/ICMBio/MMA under number 57272-1.

\section{RESULTS}

The frontal bone were extensive and flat, involving a large part of the cranium in a flat conformation, with no frontal depression and a slightly concave shape on the sides of the region between the orbits and the frontal bone (Figure 1C).

The identification of the parietal bones was marked caudally by the transverse nuchal and sagital crests, and lateroventrally by the temporal crests (Figure 1D). The boundary between frontal and parietal bones was not well-defined due to the fusion of these regions, but foramens were observed in the supraorbital region of the skull.

The zygomatic process of the squamous bone was extended in a cranio-ventral direction, and was longer than wider and with a rounded tip, that approached the most caudal and ventral region of the orbit, even reaching it in some individuals (Figure 1D).

The external ear canal showed a wide opening in lateral direction with width and height of approximate same sizes and its rostral boundary was formed by the optic process of the quadrate (Figure $1 \mathrm{D})$.

The limits of the subtemporal fossa were marked by the transversal nuchal crest, which was shown to be well developed in its dorsal region, forming an M-shaped horizontal line and the cerebellum prominence was high in the center. Its lateral proportion was little developed but visible and reached the paraoccipital processes, which were rounded projections in the caudo-ventral direction.

The parasphenoid plate was wide and triangular in shape, also the parasphenoid projection, that projected over the most caudal part of the rostroparasphenoid (Figure 1E). The parasphenoid wing presented a proeminent crest on its caudal edge. 
In the most caudal region of the skull it was observed that the foramen magnum opening was in the ventral direction. The subcondyloid fossa, ventral to the occipital condyloid process was a deep and evident structure (Figure 1J).

The presence of the hypoglossal nerve canal, the vagus nerve foramen, the ostium of the external ophthalmic canal, and the ostium of the carotid canal were observed (Figure 1J).

There was a space between the pterygoid bone and the caudal portion of the palatine bone and the pterygoid-palatine was also articulated with the rostrum of the basisphenoid. Laterocaudally the pterygoid bone articulated with the quadrate (Figure 1E). Cranial kinesis and a well-developed zona flexoria craniofacialis was observed (Figure 1C).

The crest of the palatine located at its medial portion did not reach the pterygoid bones. The palatine pneumatic foramen (Figure 1G) varied in size, some being small and others big. The vomer bone was absent. The pterygoid bone, in its most caudal part, showed the quadratic process that articulated with the condylus pterigoideus of the quadrate, and this process was well-developed and with a concave shape. The cranial extremity showed the palatine pterygoid process, that articulated cranially with the dorsal part of the palatine bone (Figure 1E) and dorsally with the parasphenoid rostrum.

The three processes of the quadrate bone were identified: orbital, mandibular and otic. Also, the condyle pterygoid, the lateral condyle, the cotyla quadrate jugal, the squamous condyle, capitulum oticum and capitulum squamosum were identified on the quadrate. The orbital quadrate process had a thin, elongated structure that was directed rostromedially with a pointed tip. The condyle pterygoid of the quadrate articulated with the pterygoid bone at each side of the skull and was located close to the medial condyle and at the extremity of the orbital process, and was directed rostromedially (Figure 1H). Two condyloid processes were identified for the mandible, the lateral and the medial (Figure 1I). The lateral condyloid process had a quadrate jugal cotyla, that articulated with the jugal, while the medial condyloid process articulated with the mandible in the quadratic articulate fossa and there was a crest in its midsection. The quadrate otic process was a long and noticeable structureand and presented the squamous and optic capitula.

The lateral orbit-nasal fonticule was bigger than the medial orbit-nasal fonticule and the orbitcranium fonticule had a wide opening in the rostral direction. The process was part of the suborbital arch and the lacrimal process was rounded in shape extending to the region of the postorbital process, where they fused and make up the suborbital arch, which was shown to be close to the jugal. The depression in the lateral side of the orbital process of the lacrimal was well marked and present at half of the height the orbit. Further in the region of the orbit, ankylosing was identified of the orbital process of the lacrimal orbit with the ectethmoid, forming the lacrimal-ecthymoid complex.

The shape of the maxillary rostrum was identified as being in the shape of an isosceles triangle. The tomialis crest of the mandible was straight and slightly concave in shape. A fossa was observed in the union site of both hemimandibles divided by a small central crest (Figure 1I).

The mandible was short and fairly high where the rostral and caudal mandible fenestras were identified (Figure 1L). The caudal mandibule fenestra is a small-sized structure, while the rostral fenestra presented a bigger opening that was easily identified, located in the third rostral of the mandible, at half its height. The retro-articulate process of the mandible was an obtuse triangular shape and the medial process of the mandible presented a small medial protuberance (Figure 1I).

The morphometric data of the skull of Amazona aestiva are shown in Table 1. 


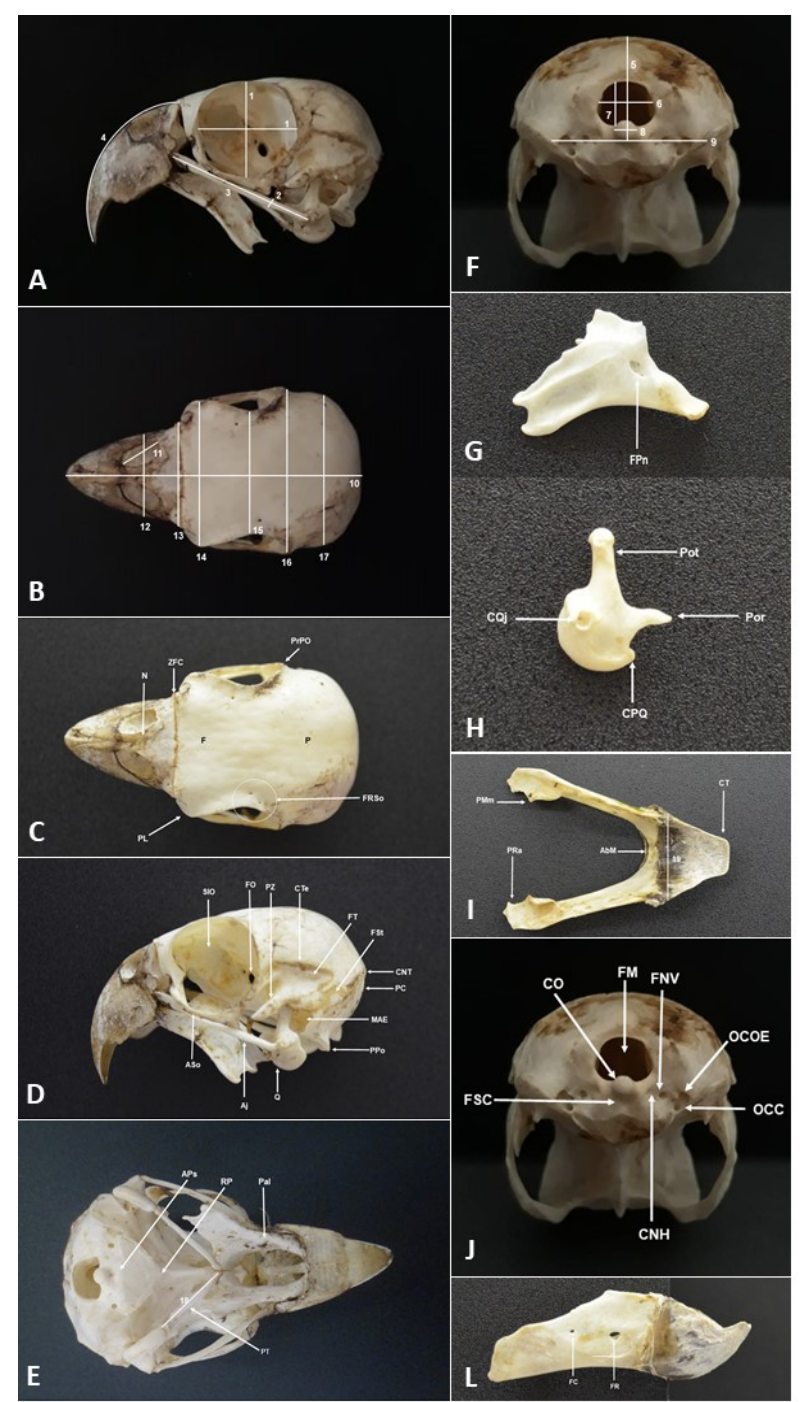

Figure 1. A. lateral view of the skull; B. dorsal view of the skull; C. dorsal view of the skull; D. lateral view of the skull; E. ventral view of the skull; F. caudal view of the skull; G. lateral view of palatine; $\mathbf{H}$. lateral view of the quadrate; I. dorsal view of the mandibule; J. caudal view of the skull ; L. lateral view of mandible. 1: orbit diameter; 2: jugal bone thickness; 3. jugal bone length; 4. rhamphoteca length; 5. maximum height without the mandible; 6. foramen magnum width; 7. foramen magnum length; 8. condylus occipitalis; 9. distance between the paraoccipital processes; 10. maximum skull length; 11. narine cranio-caudal length; 12. maximum rhamphotheca width; 13. zona flexoria craniofacialis; 14. distance between lacrimal processes; 15. distance between orbits; 16. maximum skull length; 17. maximum caudal skull width; 18. maximum gnathotheca width; AbM: bulging in the dorsal mandibule surface; Aj: jugal arch; APs: parasphenoid wing; Aso: suborbital arch; CNH: hypoglossal nerve canal; CNT: transversal nuchal crest; CO: occipital condyle; CPQ: condyle pterygoid quadrate; CQj: quadrate jugalcotyla; CT: tomial crest; CTe: temporal crest; F: frontal; FC: caudal mandibble fenestra; FN: vagus nerve foramen; FM: foramen magnum; FO: optic foramen ; FPn: palatine pneumatic foramen; FR: rostral mandible fenestra; FRSo: foramen in supraorbital region; FSC: subcondyloid fossa; FSt: subtemporal fossa; FT: temporal fossa; MAE: external ear canal; N: nasal; OCC: ostium of the carotid canal; OCOE: ostium of the external ophthalmic canal; P: parietal; Pal: palatino; PC: cerebellum promenence; PL: lacrimal process; Por: orbital quadrate process; Pot: quadrate otic process; PMm: medial process of the mandibule; PPo: paraoccipital process; PRa: retro-articulate process of the mandibule; PrPO: postorbital process; PT: pterygoid; PZ: zygomatic process; Q: quadrate; RP: rostroparasphenoid; SIO: septum interorbitale; ZFC: zona flexoria craniofacialis. 
Table 1. Mean values obtained for Amazona aestiva skulls and standard deviation in millimeters (mm)

\begin{tabular}{lc}
\hline \multicolumn{1}{c}{ Structure } & Mean and standard deviation \\
\hline Maximum skull length & $63.3 \pm 2.85$ \\
Maximum skull width & $33.0 \pm 1.38$ \\
Maximum height without the mandible & $24.3 \pm 0.99$ \\
Maximum caudal skull width & $30.4 \pm 1.01$ \\
Distance between the paraoccipital processes & $16.6 \pm 1.09$ \\
Foramen magnum length & $5.7 \pm 0.38$ \\
Foramen magnum width & $6.9 \pm 0.50$ \\
Jugal bone length & $30.9 \pm 2.10$ \\
Jugal bone thickness & $1.44 \pm 0.17$ \\
Maximum rhamphotheca width & $16.1 \pm 0.81$ \\
Rhamphotheca length & $33.8 \pm 1.92$ \\
Maximum gnathotheca width & $18.6 \pm 1.24$ \\
Narine cranio-caudal length & $7.9 \pm 0.43$ \\
Zona flexoria craniofacialis & $19.4 \pm 0.88$ \\
Distance between lacrimal processes & $28.1 \pm 1.36$ \\
Condylus occipitalis & $2.2 \pm 0.22$ \\
Orbit diameter & $17.2 \pm 0.76$ \\
Distance between orbits & $23.5 \pm 1.43$ \\
Pterygoid bone length & $17.4 \pm 1.37$ \\
\hline
\end{tabular}

\section{DISCUSSION}

The absence of frontal depression in the skull of the Amazona aestiva showed greater similarity with other birds such as Geotrygon montana (Columbiformes) (MARCELIANO et al., 2007), Anhima cornuta and Chauna chavaria (Anseriformes) (PREVIATTO, 2012) that also didn't have the frontal depression. However, birds of prey such as Milvago (Falconiformes) (GUZZI et al., 2015b), Micrastur semitorquatus (Falconiformes) (SILVA et al., 2012) and Micrastur ruficollis (Falconiformes) (GUZZI et al., 2014b) have this feature.

The concave shape on the sides of the frontal bone identified in Amazona aestiva were described by Posso and Donatelli (2007) for some members of the subfamily Coccyzinae (Cuculiformes) and by Previatto and Posso (2015) for Cyclarhis gujanensis (Passeriformes). According to Burton (1984), this feature is associated to widening of the visual field. The caudal boundary of the parietal bone was similar to that described by Previatto (2012) and latero-ventrally was in agreement with the description by Guzzi et al. (2014a) for Mycteria (Ciconiiformes). According to Guzzi et al. (2015b), individuals of the species Milvago chimachima and Milvago chimango present depression of the temporal fossa delimitated dorsally by the temporal crest and ventrally by the transverse nuchal crest, but individuals of the species Amazona aestiva present the subtemporal fossa, as do individuals of the species Chloroceryle amazona (Coraciiformes) described by CalongeMendéz and Höfling (2007), and in this case, the subtemporal fossa was bounded by the transverse nuchal crest. The presence of the hypoglossal nerve canal, the vagus nerve foramen, the external ophthalmic canal ostium and the carotid canal ostium were in agreement with the description by Baumel et al. (1993).

The proximity of the suborbital arch to the jugalis a characteristic also described for examples of parrots including Psittacara frontatus (Psittaciformes) by Ferraroni (2015). The suborbital arch in exclusive to parrots corresponds to the suborbital ligament ossification, forming the infraorbital margin of the orbit (CANDIOTO, 2011). Parrots may have complete or incomplete suborbital arch, that has a similar function of providing support to the eye (MACHADO et al., 2006).

The presence of a well developed zona flexoria craniofacialis observed in Amazona aestiva is a characteristic of the order Psittaciformes. This peculiarity gives these animals a greater flexibility of movement, that may help in their feeding habits, that include the need to break open nuts and coconuts, and can also help in their movement habits that include climbing by using the beak and feet (GRESPAN; RASO, 2014).

According to Baumel et al. (1993), the mandible rostral fenestra and the mandible caudal fenestra are characteristics to some species of Psittaciformes, but Ferraroni (2015) demonstrated that some species of the genus Aratinga (Psittaciformes) did not present the mandible caudal fenestra and Souza et al. (2017b) demonstrated that Forpus xanthopterygius (Psittaciformes) has only the mandible rostral fenestra. Amazona aestiva matched the description made by the first author, 
because all the specimens presented both rostral and caudal fenestras.

The mandible in birds such as chickens contributed little to the skull height (FEDDUCIA, 1986), but in Amazona aestiva, as in all Psittacifomes, as show by Porto (2004) for several species of this order, it was short and fairly tall and these characteristics were in line with the eating habits, that include the need to break seeds. According to Kardong (2016), because the mandible is short and robust, force is concetrated more efficiently at the base of the beak to close it.

The projection of the parasphenoid plate over the most caudal part of the rostrum parasphenoid was similar to that described for Ciconiiformes (FERREIR; DONATELLI, 2005) and for individuals of the family Nyctibiidae (Caprimulgiformes) (COSTA; DONATELLI, 2009).

Some authors have reported that the mandible process of the quadrate presents four different condyloid processs (SILVA et al., 2012; GUZZI et al., 2015b) while some authors describe the mandible process with two condyloid processes (LADEIRA; HÖFLING, 2007; COSTA; DONATELLI, 2009). The presence of two condyloid processes were observed for Amazona aestiva in the present study. The quadrate otic process was similar to that described in the literature in birds such as Bucconidae (Piciformes) (LADEIRA; HÖFLING, 2007) and Nyctibiidae (COSTA; DONATELLI, 2009). The rostromedial direction of the orbital process, that is thin and elongated, has also been described in the literature for Megaxenops parnaguae (Passeriformes) (DONATELLI; MARCELIANO, 2007). The quadrate bone is very important regarding cranial kinesis, since it articulates the skull with the jugal and pterygoid bones raising the maxilla when the mandible is lowered (O'MALLEY, 2005).

The orbits circular in shape and therefore its height and width do not present different values so that it was verified that when the orbit width was compared to the maximum skull length, the first represented $22.1 \%$ of the second measurement. This is in line with the general description for many birds that have large orbits (GRESPAN; RASO, 2014; CAVINATTO et al., 2016).

The distance between the orbits represented $71.2 \%$ of the maximum skull width and $77.3 \%$ of the maximum skull caudal width. Souza et al. (2017a) studied Diopsittaca nobilis (Psittaciformes) and reported that these same proportions were, respectively, $71.1 \%$ and $74.4 \%$, and did not present significantly different values. A large skull is associated to a larger area of muscle insertion in Falconidaes, that positively influences their way of feeding, and is a mechanical advantage (SUSTAITA, 2008). In the present study, large proportions were also observed, that may be directly linked to the fact that the feeding of Amazona aestiva includes hard seeds and the need to break them with the beak.

The rhamphotheca length represented $53.3 \%$ of the maximum skull length, similar to that described by Previatto (2012) in his studies on examples from the family Anhimidae (Anseriformes), by Ladeira and Höfling (2007) for Bucconidae, by Posso and Donatelli (2007) for Coccyzinae and by Marceliano et al. (2007) for Geotrygon montana.

The narine represented $23.3 \%$ of the rhamphotheca length, less than that observed by Pascotto et al. (2006) for examples of Todidae and Brachypteraciidae (Coraciiformes), where the narine represented about $40 \%$ of the upper maxilla length. The narine of the Amazona aestiva represented $12.4 \%$ of the maximum skull length, that was less than that observed by Ladeira and Höfling (2007) for Bucconidae where the narine represented $30 \%$ of the skull length.

The zona flexoria craniofacialis in a study by Souza et al. (2017a) for Diopsittaca nobilis represented $62.2 \%$ of the maximum skull width and $65.1 \%$ maximum caudal width. In Forpus xanthopterygius (SOUZA et al., 2017b) the craniofacial flex zone represented $54.6 \%$ of the maximum skull width and $55.0 \%$ of the maximum caudal width. In the present study the values were found of $58 \%$ for the maximum width and $63.1 \%$ for the maximum caudal width, and this was an intermediate value between the two parrot species.

The foramen magnum width of Amazona aestiva represented $22.6 \%$ of the skull maximum caudal width, while in Diopsittaca nobilis (SOUZA et al., 2017a) this value was 20.2\% and in Forpus xanthopterygius (SOUZA et al., 2017b) it was $18.2 \%$, so that the foramen magnum of the Amazona aestiva has a relatively bigger opening for the passage of the spinal chord.

No significant differences were observed between males and females and Amazona aestiva demonstrated characteristics expected for species of the order Psittaciformes, which are specially focused on their eating habits, such as the strong, broadbent recurved beak and well developed zona flexoria craniofacialis, and the morphological characteristics of the bird skull of this order are very high, uniforms with each other. Although the skull of the Amazona aestiva presented the same bones 
Anatomy and morphometry...

and structures previously observed and described in other examples of birds, various anatomic characteristics, especially regarding the morphometric measurements, characterized the skull of adults of this species and serves as a base for further knowledge for comparative anatomy, in the identification and characterization of the species.

\section{ACKNOWLEDGEMENTS}

SOUZA, J. G. et al.

The authors thank the Federal University of Campina Grande and the Brazilian Institute of the Environment and Renewable Natural Resources for support for this research.

\section{CONFLICTS OF INTEREST}

The authors declares that they have no conflict of interest related to the publication of this manuscript.

RESUMO: A obtenção de dados craniométricos é fundamental para o estabelecimento de parâmetros que auxiliem na identificação anatômica e na compreensão das espécies. O objetivo do presente estudo foi estabelecer os dados craniométricos e descrever os principais ossos e estruturas do crânio do Amazona aestiva, que se tornou comum em clínicas veterinárias, oriundos de aquisição legal ou tráfico de animais. Foram utilizados 20 indivíduos adultos, doados para estudos do Centro de Triagem de Animais Silvestres da Paraíba (CETAS-PB) / IBAMA-PB, Brasil. Os crânios foram dissecados e macerados com água. Identificaram-se os ossos frontal, maxilar, mandibular, nasal, jugal e quadrado, que serviram de base para identificar outras estruturas ósseas que foram então, comparadas com o crânio de outras espécies de aves já descritas na literatura, principalmente psitacideos. Valores numéricos foram adquiridos através de mensuração com paquímetro digital, sendo o comprimento máximo do crânio de $63,0 \mathrm{~mm}$, largura máxima de $33,0 \mathrm{~mm}$ e ranfoteca de 33,8 mm de comprimento. Não foram observadas diferenças significativas entre machos e fêmeas e, uma craniocinese bem desenvolvida foi característica marcante da espécie. Os dados obtidos servem de base para identificar e caracterizar as espécies. Estes dados também podem auxiliar na clínica, imagem e cirurgia veterinária.

PALAVRAS CHAVE: Morfologia. Morfometria. Psittacidae.

\section{REFERENCES}

BAUMEL, J. J.; KING, A. S.; BREAZILE, J. E.; EVANS, H. E.; BERGE, J. C. V. Handbook of avian anatomy: Nomina anatomica avium. 2. ed. Massachussets: Nuttall Ornithological Club, 1993.

BURTON, P. J. K. Anatomy and evolution of the feeding apparatus in the avian orders Coraciiformes and Piciformes. Bulletin of the British Museum (Natural History), v.47, n.6, p.331-443, nov. 1984.

CALONGE-MÉNDEZ A.; HÖFLING E. Osteologia craniana de Cerylinae (Coraciiformes: Alcedinidae). Ciências Naturais, v.2, n.1, p.155-182, jan-abr. 2007.

CANDIOTO, C. G. Histomorfometria do bulbo do olho de peneireiro-de-dorso-malhado (Falco tinnunculus - LINNAEUS, 1758). 2011. Dissertação (Mestrado em Medicina Veterinária) - Faculdade de Ciências Agrárias e Veterinárias, Universidade Estadual Paulista, Jaboticabal.

CAVINATTO, C. C.; ARMANDO, A. P. R. N.; CRUZ, L. K. S.; LIMA, E. M. M.; SANTANA, M. I. S. Descrição anatômica de esqueletos de papagaios do gênero Amazona através da utilização de radiografias. Pesquisa Veterinária Brasileira, v.36, n.2, p.123-130, fev. 2016. http://dx.doi.org/10.1590/S0100736X2016000200010.

COSTA, T. V. V.; DONATELLI, R. J. Osteologia craniana de Nyctibiidae (Aves, Caprimulgiformes). Papéis Avulsos de Zoologia, v.49, n.21, p.257-275, 2009. http://dx.doi.org/10.1590/S0031-10492009002100001.

DONATELLI, R. J.; MARCELIANO, M. L. V. Osteologia e miologia cranianas de Megaxenops parnaguae (Furnariidae: Philydorinae). Ciências Naturais, v.2, n.1, p.183-215, jan-abr. 2007. 
FEDDUCIA, A. Osteologia das aves. In: GETTY, R. Anatomia dos Animais Domésticos. 5.ed. Rio de Janeiro: Interamericana, 1986. p. 1680-1690.

FERRARONI, A. Taxonomia e filogenia de Aratinga Spix 1824 (Aves: Psittacidae). 2015. Tese (Doutorado em zoologia) - Instituto de Biociências da Universidade de São Paulo, São Paulo.

FERREIRA, C. D.; DONATELLI, R. J. Osteologia craniana de Platalea ajaja (Linnaeus) (Aves, Ciconiiformes), comparada com outras espécies de Threskiornithidae. Revista Brasileira de Zoologia, v.22, n.3, p.529-551, set. 2005. http://dx.doi.org/10.1590/S0101-81752005000300003.

GRESPAN, A.; RASO, T. F. Psittaciformes (Araras, Papagaios, Periquitos, Calopsitas e Cacatuas). In: CUBAS, S. Z.; SILVA, R. C. J.; DIAS, C. L. J. 2. ed. Tratado de animais selvagens. São Paulo: Rocca, 2014. p. $550-589$.

GUZZI, A.; NASCIMENTO, M. S.; LIMA, S. P.; SANTOS, S. S.; DONATELLI, R. J. Osteologia craniana e aspectos evolutivos de Mycteria (Aves: Ciconiidae). Revista Nordestina de Biologia, v.23, p.85-102, 2014a.

GUZZI, A.; SANTOS, F. C. V.; FERREIRA, G. J. B. C.; DONATELLI, R. J. Comparative analysis of the cranial osteology and evolutionary traits of Micrastur gilvicollis, Micrastur ruficollis and Micrastur semitorquatus (Aves: Falconiformes). Revista Nordestina de Zoologia, v.8, n.1, p.70-88, jan-jun. 2014b.

GUZZI, A.; CASTRO, J. M. N.; MARTINS JUNIOR, R. N. C.; DONATELlI, R. J.; SOARES, L. M. S.; FERREIRA, G. J. B. C. Osteologia craniana comparada de Caracara cheriway (Jacquin, 1784) e Caracara plancus (Miller, 1777) (AVES: FALCONIDAE). Ciência e Natura, v.37, n.2, p.218-229. mai-ago. 2015a.

GUZZI, A.; SANTOS, A. M.; SANTOS, J. D.; DONATELLI, R. J.; FERREIRA, G. J. B. C. Principais caracteres da osteologia craniana de Milvago chimango (Vieillot, 1816) e Milvago chimachima (Vieillot, 1816) (Aves: Falconidae). Biotemas, v.28, n.3, p.107-119. set. 2015b. https://doi.org/10.5007/21757925.2015v28n3p107.

KARDONG, K. V. Vertebrados: anatomia comparada, função e evolução. 7. ed. Rio de Janeiro: Guanabara Koogan, 2016.

LADEIRA, L. M. C. E. B.; HÖFLING, E. Cranial osteology of Bucconidae. Ciências Naturais, v.2, n.1, p.117-153, jan-abr. 2007.

MACHADO, M.; SCHMIDT, E. M. S.; FERREIRA, F. M. Interspecies variation in orbital bone structure ospsitaci form birds (with emphasison Psittacidae). Veterinary Ophthalmology, v.9, n.3, p.191-194, mai. 2006. http://dx.doi.org/10.1111/j.1463-5224.2006.00456.x

MARCELIANO, M. L. V.; DONATELLI, R. J.; POSSO, S. R. Osteologia e miologia cranianas de Eurypyga helias (Pallas, 1781) (Gruiformes: Eurypygidae) comparada com outros Gruiformes. Ciências Naturais, v.2, n.1, p.69-86, jan-abr. 2007.

NICKEL, R.; SCHUMMER, A.; SEIFERLE, E. Anatomy of the Domestic Birds. Berlin: Parey, 1977.

O'MALLEY, B. Clinical anatomy and physiology of exotic species: Structure and function of mamals, birds, reptiles and amphibians. 1. ed. Philadelphia: Elsevier, 2005.

PASCOTTO, M. C.; HÖFLING, E.; DONATELLI, R. J. Osteologia craniana de Coraciiformes (Aves). Revista Brasileira de Zoologia, v.23, n.3, p.841-864, set. 2006. http://dx.doi.org/10.1590/S0101-81752006000300032

PORTO, M. Anatomia comparada do esqueleto da cabeça e da musculatura da mastigação de Anodorhynchus Spix, 1824, Ara Lacépède,1799, Diopsittaca Ridgway, 1912, Phophyrrura Miranda-Ribeiro, 
1920 e Orthopsittaca Ridgway, 1912 (Aves: Psittaciformes: Arinae). 2004. Tese (Doutorado em Ciências) Universidade Federal Rural do Rio de Janeiro, Seropédica.

POSSO, S. R.; DONATELLI, R. J. Osteologia craniana e considerações sistemáticas em Coccyzinae (Cuculidae). Boletim do Museu Paraense Emílio Goeldi. Ciências Naturais, v.2, n.1, p.87-116, jan-abr. 2007.

PREVIATTO, D. M. Osteologia craniana da família Anhimidae (Aves: Anseriformes). 2012. Dissertação (Mestrado em Ciências Biológicas) - Instituto de Biociências de Botucatu, Universidade Estadual Paulista Júlio de Mesquita Filho, São Paulo.

PREVIATTO, D. M.; POSSO, S. R. Cranial osteology of Cyclarhis gujanensis (Aves: Vireonidae). Papéis Avulsos de Zoologia, v.55, n.18, p.255-260, 2015. http://dx.doi.org/10.1590/0031-1049.2015.55.18

SILVA, A. G.; FERREIRA, G. J. B.; DONATELLI, R. J.; GUZZI, A. Osteologia craniana de Micrastur semitorquatus Vieillot, 1817 (Falconiformes: Falconidae). Comunicata Scientiae, v.3, n.1, p.64-71, 2012. https://doi.org/10.14295/cs.v3i1.99

SILVEIRA, L. F.; HÖFLING, E. Osteologia craniana dos Tinamidae (Aves: Tinamiformes), com implicações sistemáticas. Ciências Naturais, v.2, n.1, p.15-54, jan-abr. 2007.

SOUZA, J. G.; CARREIRO, A. N.; FALCÃO, B. M. R.; OLIVEIRA, M. G.; VIEIRA, A. K. R.; SANTOS, J. R. S.; MEDEIROS, G. X.; MENEZES, D. J. A. Aspectos anatômicos e morfométricos do crânio de maracanãpequena - Diopsittaca nobilis Linnaeus, 1758. PubVet, v.11, n.9, set. 2017 a. http://dx.doi.org/10.22256/pubvet.v11n9.848-853

SOUZA, J. G.; CARREIRO, A. N.; LA SALLES, A. Y. F.; FIGUERÊDO, M. B. S.; ABRANTES, S. H. F.; SANTOS, J. R. S.; MENEZES, D. J. A. Morfometria e craniometria de Tuim-de-asa-azul (Forpus xanthopterygius Spix, 1824). PubVet, v.11, n.4, p.3 93-398. abr. $2017 \mathrm{~b}$. http://dx.doi.org/10.22256/pubvet.v11n4.393-398

SUSTAITA, D. Musculoskeletal underpinnings to differences in killin behavior between North American accipiters (Falconiformes: Accipitridae) and falcons (Falconidae). Journal of Morphology, v.2, n.3, p.283301. abr. 2008. https://doi.org/10.1002/jmor.10577 